\section{Taxonomic Problems in Cultivated Liriopogons}

\author{
Paul R. Fantz
}

\begin{abstract}
Additional index words. nomenclature, Liriope, Ophiopogon, Convallariaceae, Liliaceae, ornamentals, ground covers
\end{abstract}

Summary. Liriopogons (Liriope, Ophiopogon) are versatile landscape plants with a complexity of taxonomic problems. A taxonomic revision of liriopogons cultivated in the United States is needed; one that includes an inventory of taxa, quantitative descriptions of species and cultivars, keys and other aids for segregation and identification of taxa, documentation of taxa with vouchers deposited in herbaria, and establishment of a living germplasm collection that can serve as a standard for the nursery/ landscape industries.

B ailey (1929) used the term Liriomondos to refer to cultivated members of the genera Liriope Lour. and Mondo (Kaempf.) Adans. The name Ophiopogon KerGawl. has been conserved according to the international rules (Voss 1983), thus reducing the name Mondo to synonymy, and recognizing Ophiopogon as the correct name for this genus. Accordingly, Bailey's Liriomondos was altered by Skinner (1971) to Liriopogons, a useful name when discussing the complex group because it is difficult in the nursery/landscape industries to identify species and segregate the genera. Bailey (1929) noted "the plants are commonly misnamed in nurseries and the pictures in books are not reliable; specimens are likely to be wrongly determined in herbaria."

The liriopogons are acaulescent plants with grass-like leaves and small, lilac to violet or white flowers clustered in fascicles on scapes among the

Department of Horticultural Science, North Carolina State University, Box 7609, Raleigh, NC 27695-7609. ${ }^{\text {'Professor. }}$

Research Project NCO 6104 funded by the North Carolina Agricultural Research Service, Raleigh, NC 27695-7643. foliage. Leaves may be green or variegated with marginal bands, longitudinal stripes, or, occasionally, with transverse bands of creams, yellows, white, or silver.

Liriopogons commonly are known under several vernacular names in the trade, "lilyturfs" (usually applied to Liriope spp.), "mondo grass" (usually applied to Ophiopogon spp.), and "monkey grass" and "Aztec grass" (both applied across generic lines). They are versatile landscape plants, being used as groundcovers, foundation plants, understory plants for woody crops, edging and massing, and in combination with a wide variety of perennials, shrubs, and trees.

Liriopogons are noted as durable, adaptable low-maintanence evergreens with no serious pest problems. They are moderately drought-resistant and useful in sun or shade (Adams, 1989; Batson, 1984; Dirr, 1983; Flint, 1983; Halfacre and Shawcroft, 1989; Hudak, 1985; Hume and Morrison, 1963; Odenwald and Turner, 1980; Skinner, 1971; Still, 1988; Thomas, 1982; Voigt et al., 1983; Wyman, 1977).

Liriopogons are becoming an increasingly important landscape crop in today's trade. Nurseryworkers, landscapers, and recent authors (Adams, 1989; Batson, 1984; Dirr, 1983; Flint, 1983; Halfacre and Shawcroft, 1989; Hudak, 1985; Hume and Morrison, 1963; Odenwald and Turner, 1980; Skinner, 1971; Still, 1988; Thomas, 1982; Voigt et al., 1983; Wyman, 1977) currently recognize five species in the trade, namely L. muscari (Decne.) Bailey, L. spicata Lour., $O$. jaburan (Sieb.) Lodd., O. japonicus (Thunb.) Ker-Gawl, and O. planiscapus Nakai. The taxonomic problems of liriopogons have increased in complexity since Bailey, as outlined below.

\section{Taxonomic history}

Thunberg (1780) described the species Convallaria japonica. This is the origin of plants known today as $O$. japonicus.

Loureiro (1790) proposed the genus Liriope in describing plants from Cochinchina (presently Cambodia, Laos, Vietnam). This is the origin of the plants known presently as $L$. spicata.

Ker-Gawl (1807) proposed the genus Ophiopogon based on Thunberg's species that he recognized as misassigned to the genus Convallaria. Ker-Gawl (1821) assigned Loureiro's species to Ophiopogon as O. spicatus.

Siebold (1830) described the species Slateria jaburan from Japan. Loddiges (1832) assigned Siebold's species to Ophiopogon, presently known as $O$. jaburan.

Decaisne (1868) described the species $O$. muscari. This is the origin of the plant currently known in the trade as $L$. muscari.

Nakai (1920) described the species $O$. planiscapus presently known in cultivation. This is the last of the five commonly known cultivated species to be described.

Farwell (1921) reported that the generic name Mondo (Adanson 1763) had priority over Ophiopogon. Farwell transferred all species to the genus Mondo. Lacking common names, this is the probable source of plants in the genus becoming known as "mondo grasses" in cultivation.

Bailey (1929) provided the first major treatment of this cultivated group of plants, referring to them as liriomondos or lilyturfs. He summarized their cultural uses and nomenclatural history.

Bailey noted that several authors combined the taxa under one genus, but correctly concluded that there were two differentiated genera named Mondo Adans. (syn. Ophiopogon KerGawl) and Liriope Lour. A key was provided to the seven species of Mondo and two species of Liriope, along with descriptions. No cultivars were noted. Bailey transferred Descaisne's name to Liriope as L. muscari and described briefly two varieties as var. variegata and var. exiliflora.

Bailey's species $M$. japonicum Farw., M. jaburan (Sieb.) Bailey, $M$. planiscapum (Nakai) Bailey, L. spicata Lour. and L. muscari (Decne.) Bailey are commonly known cultivated species in the United States. Mondo dracaenoides (Bak.) Farw., M. intermedium (D. Don) Bailey, and M. wallichianum (Kunth) Bailey are not currently reported to be in cultivation as liriopogons.

The Sixth International Botanic 
Congress met in Amsterdam in 1935. A number of generic names were conserved over synonyms and earlier published generic names. These are included in Appendix III of the "International Code of Botanic Nomenclature," the international rules governing plant names. The generic name Ophiopogon was conserved over the generic name Mondo as the correct name for the genus. Rickett and Stafleu (1959) began publishing a list of conserved and rejected names in Taxon, the journal of the International Assn. for Plant Taxonomy.

Hume (1961) provided a revised treatment of the lilyturfs. He reported that the generic name Mondo must be abandoned in favor of the conserved generic name Ophiopogon, following the adoption by the International Botanic Congress of Amsterdam in 1935. He recognized three species$O$. jaburan, O. japonicus, and $O$. arabicus $[=O$. planiscapus] - the latter name found without a published description. These are the same commonly cultivated species of mondo grasses recognized by Bailey (1929).

Hume (1961) also provided several changes in his treatment of Liriope. He recognized five species- L. muscari, L. spicata, L. graminifolia (L.) Bak., L. exiliflora (Bailey) Hume, and L. gigantea Hume - the latter pair newly described. He also described cultivars for the first time, including 'Vittata' of $O$. jaburan and 11 cultivars of $L$. muscari: 'Big Blue', 'Blue Spire', 'Christmas Tree', 'Curly Twist', 'Eleven-O-Three', 'Gold-banded', 'Lilac Beauty', 'Majestic', 'Monroes White', 'Silver Banded', and 'Variegata'. No key was provided to taxa.

Hume and Morrison (1963) provided cultural uses of lilyturfs and a brief inventory of additional new cultivars, including L. muscari: 'Border Gem', 'Cockscomb', 'Grandiflora', 'New Wonder', 'Silvery Midget', and 'Silvery Sunproof.

Wang and Tang (1951) rejected Bailey's transfer of Decaisne's basionym muscari and proposed a new name, $L$. platyphylla, for the commonly cultivated species. Meyer and Walker (1965) published an English translation of Ohwi's Flora of Japan, accepting the name L. muscari (Descn.) Bailey in synonymy of L. platyphylla Wang \& Tang. However, Makino (1961) cited L. platyphylla Wang \& Tang as a synonym of L. graminfolia Baker. Jessop
(1983) cited L. muscari auth. (non Bailey) as a synonym of $L$. graminifolia Baker. Hara (1984) recognized Bailey's transfer as legitimate and cited $L$. platyphylla Wang \& Tang as a synonym of L. muscari Bailey, as did Huxley (1992).

Skinner (1971) proposed the vernacular name "liriopogon" for this cultivated group. His inventory of taxa included brief descriptions of taxa. He adopted the name L. platyphylla based upon Meyer and Walker (1965) transferring 15 cultivar names to this species from L. muscari. He noted the name $O$. arabicus as synonymous with $O$. planiscapus, and noted $O$. intermedius as apparently not cultivated in America.

\section{Taxonomic problems}

First, there is presently no thorough inventory of the cultivated liriopogons. The major contributions include Bailey (1929) and the moremodern revisions by Hume (1961), Hume and Morrison (1963), and Skinner (1971). These moderninventories are incomplete and out-of-date; they recognize five species and nearly 20 cultivars. If one begins to assemble names of available liriopogons cultivated in the United States based on literature and catalogues, one can find more than 20 named species (Table 1) and more than 100 named cultivars (Table 2), even after elimination of similar names.

Second, detailed descriptions of taxa are lacking, both at the level of species and cultivars. Descriptions typi-

Table 1. A checklist of names of cultivated liriopogon species.

\begin{tabular}{ll}
\hline Liriope sp. & \multicolumn{1}{c}{ Ophiopogon sp. } \\
\hline L. exiliflora & O. arabicum \\
L. gigantea & O. chekangensis \\
L.graminifolia & O. clarkei \\
L. grandiflora & O.graminifolia \\
L. hyacinthiflora & O. intermedia \\
L. japonica & O. intermedius \\
L. kansuensis & O. jaburan \\
L. minor & O. japonicus \\
L. muscari & O. nana \\
L. platyphylla & O. obwii \\
L. spicata & O. planiscapus \\
& O. nigra \\
& O. nigrescens \\
& O. spicatus \\
& O. wallichianus
\end{tabular}

${ }^{z}$ Listed also as Otheopogum. cally are brief. They often use characteristics that could apply to several selections and relative terms that are open to misinterpretation. Good quantitative descriptions are needed for comparison and delimitation of taxa.

Third, identification aids are scarce. Illustrated identification guides are limited. Taxonomists use keysdichotomous statements that present contrasting morphological characteristics-to segregate taxa. Similar keys are needed for liriopogons.

Fourth, there is a lack of representative specimens of species and cultivars deposited in herbaria. Vouchers of identified liriopogons can be used for morphological comparison and aiding identification of unknowns. Liriopogon specimens are rare to nonexistent in some major herbaria in the United States. Larger herbarium collections of liriopogons need critical examination as surveys of species reveal mixed material filed under each name. This makes it difficult for one to ascertain the boundaries of the species and identify unknown cultivated species. Botanical gardens and arboreta are important repositories for living germplasm collections. Unfortunately, liriopogons are represented poorly in these collections, and they frequently contain mixed material filed under one name.

Fifth, there is no revision geographically or monograph of liriopogons worldwide. Liriopogons are native to Asia, introduced into the United States via cultivation; however, most Asian countries lack floras. This lack of key literature references is a major obstacle in being able to identify accurately those species that are found in cultivation in the United States.

Sixth, a number of nomenclatural questions need to be resolved, from the family level downwards. An ordering of the nomenclature is needed to provide the correct name for the taxon plus the available synonyms.

Family. The familial relationship of liriopogons is unclear among modern botanists. Traditionally, liriopogons were included within the family Liliaceae, a family whose delimitation is much disputed because of a number of aberrant members, such as the liriopogons. This has lead botanists to assign liriopogons to the Convallariaceae, Haemodoraceae, or Ophiopogonaceae. Dahlgren et al. 
Table 2. A checklist of names of cultivated liriopogon cultivars.

\begin{tabular}{|c|c|c|c|}
\hline Alba & Fedwell Big Blue & Majestic & Silver Banded \\
\hline Angustifolia & Folius Albostriatus & Majestic Blue & Silver Dragon \\
\hline Arabicus & Folius Aureopunc- & Majestic Variegated & Silver Mist \\
\hline Argenteo-variegatus & tatus & Miniature & Silver Showers \\
\hline Argenteo-vittatus & Franklin Mint & Minor & Silvery Dragon \\
\hline Ariake Janshige & Gilner White & Monroe & Silvery Midget \\
\hline Aritaki & Gold Banded & Monroe no. 1 & Silvery Sunproof \\
\hline Aureus & Grandiflora & Monroe no. 2 & Striatus \\
\hline Aztec & Grandiflora White & Monroe White & Sunproof \\
\hline Big Blue & Green Midget & Monroes White & Superba \\
\hline Big Blue Regal & Gyoko-Ryu & Moores White & Tamaryu Nishiki \\
\hline Big Green & Gyoku-Ryu & Monroei White & Tidewell's Big Blue \\
\hline Black Dragon & Hakuryu & Monroi White & Tidwells Big Blue \\
\hline Blue Cushion & Hakuryu Dwarf & Munroe White & Tokai-rinpa \\
\hline Blue Spire & Hakuryu Ko & Nana & Torafu \\
\hline Border Gem & Hawks Feather & Nanus & Traebert White \\
\hline Caeruleus & Improved Muscari & New Orleans & Variegata \\
\hline C.T. Tanner & Ingwersen & New Wonder & Variegata Alba \\
\hline CT Tanner & Intermedia & Nigrescens & Variegata White \\
\hline Christmas Tree & Javanensis & Nippon & Variegated \\
\hline Cockscomb & Jeanerette & Nuscari & Variegated Ever- \\
\hline Compact Blue & John Burch & Original Big Blue & green Giant \\
\hline Compactus & Kigimafukiduma & Peedee Ingot & Variegated White \\
\hline Crows White & Kioto & Purple Boquet & Flowered \\
\hline Crested White & Kiyoto & Regal & Variegatus \\
\hline Curly Twist & Korean Variegated & Rocket & Webber \\
\hline Densiflora & Kyoto Dwarf & Royal Purple & Webster Wideleaf \\
\hline Ebony & Leucanthus & Samantha & White on White \\
\hline Ebony Knight & Lilac Beauty & Sheffield & Wonder Evergreen \\
\hline Eleven-O-Three & Magestic & Shiro Tama Hime & Xmas \\
\hline Evergreen Giant & Majectic & Shiroshima Ryu & Xmas Tree \\
\hline
\end{tabular}

(1985) used anatomical, chemical, cytological, developmental, embryological, morphological, and palynological studies to revise the monocot families. They assigned liriopogons to the order Asparagales, family Convallariaceae, tribe Ophiopogoneae, well-segregated from the traditional order Liliales, family Liliaceae. Cronquist (1988), the recognized American authority, maintained the traditional view of assigning liriopogons to the Liliaceae.

Genus. Genera are defined poorly in the landscape/nursery trade. Nurseryworkers/landscapers appear to rely on growth habit, leafwidth, and flower color as the main characters for segregation. Therefore, plants frequently are misidentified to genus. Adams (1989) reemphasized, and several earlier authors found, that flower position was "the best characteristic for identifying the genus," with flowers of Ophiopogon hanging down and flowers of Liriope being erect.

Species. Delimitation of species is poorly understood in the trade. Nurseryworkers/landscapers identify Ophiopogon planiscapus by its purplish-black foliage. Ophiopogon japonicusis identified by its narrow leaves, creeping matforming habit, short height, and blue fruit hidden among the foliage. Liriope spicata is identified as a creeper with tall, narrow leaves and scapes within the leaves. Liriope muscari is identified as a clumper with broad leaves and scapes above the leaves. Nurseryworkers have more difftculty identifying Liriope sp. than Ophiopogon sp. due to their greater variability in growth habit, leaf size, variegation, and flower color.

There are impostors masquerading under several species names. For example, Hume's (1961) L. exiliflora and $L$. gigantea are found within $L$. muscari. Nearly all nurseryworkers/ landscapers are unaware of these two names proposed by Hume. Plants sold under the name $O$. japonicus includes four species. Ophiopogon jaburan is a mystery to many in the trade who are unfamiliar with the plant. Those familiar with "Aztec grass" regard it as a mutated Liriope because of its size, yet these plants actually belong to the genus Ophiopogon.

Wang and Tang (1951) of China proposed the name of $L$. platyphylla as correct for plants bearing the name $L$. muscari. This is the one species presently cultivated in the United States with the largest number of named cultivars. Nurseryworkers appear to be unaware of this name change, despite Meyer and Walker (1965) and Skinner (1971) adopting this name and transferring cultivars to the newer name. Some botanical gardens (e.g., United States National Arboretum; Royal Botanic Gardens, Kew) now bear this newer name on their labels. However, plants of L. platyphylla obtained from China by the North Carolina State Univ. Arboretum are not equivalent to our cultivated plants labeled as $L$. muscari. This is a complex nomenclatural problem that needs to be res o l v e d.

Cultivars. Differentiation of cultivars is particularly difficult. There are several complexes of closely related names, yet nurseryworkers recognize different selections. 'Variegata' is a common name applied to selections in several species, as is 'Alba', 'Big Blue', and 'Majestic'. Nurseryworkers segregate cultivars according to leaf morphology, floral color, inflorescence apex, and habit. Mularoni and Anderson (1987) studied the influence of environmental factors, including temperature, photoperiod, and fertility on the growth of one unnamed cultivar of L. muscari. They concluded that variability associated with leaf morphology and flower color could be environmentally induced; thus, these were not appropriate taxonomic characters. Additional morphological characters with quantitative components are needed for delimitation of cultivars and their segregation.

Cultural practices. Nurseryworkers use several cultural practices that degrade cultivar integrity (Fantz 1991a-c), and create nomenclatural problems in liriopogons. Sexual reproduction, for instance, is a leading cause of taxonomic problems. Nurseryworkers obtain more propagules by harvesting and growing seeds from cultivars than by divisions. Seedlings are assigned the same cultivar name as the parent plant from which seeds were obtained, but the seedlings also contain genetic information from an unknown parent. This practice results in modification of morphological expression, and cultivar degradation over time. 
A second practice that causes cultivar degradation is plant substitution. Some nurseryworkers substitute cultivars when filling an order without informing the customer of the substitution or cultivar switch.

A third cultural problem that leads to cultivar confusion is seedling invasion. Liriopogons are both field- and container-grown. Seedling invasion can occur in field-grown crops by seed germination within a cultivar bed or by invasion of a neighboring cultivar that is stoloniferous and produces daughter plantlets. Yet, all plants harvested from a bed are sold under the same cultivar name. Seedling invasion also occurs when seeds from adjacent selections germinate in another cultivar's bed or pot.

A fourth cultural practice causing cultivar identification problems is labeling. Some nurseryworkers label beds instead of individual plants. This results in cultivars being identified by location, not by morphology. When windstorms, animals, customers, or workers remove labels, they often are replaced by the "guesstimate" method, leading to potential misidentification. Furthermore, workers copying plant labels can make spelling errors, such as observed in the names 'Monroe', 'Monroe White', 'Munroe White', 'Monroi White', 'Mooroe White', and 'Moores White'. Sometimes names are changed inadvertently, such as 'Xmas Tree' or 'Xmas', as a shortened form of 'Christmas Tree'.

Landscapers and nurseryworkers are being held increasingly more accountable for correct plant names. Taxonomic problems create disputes between some nurseryworkers, landscapers, and their customers that may have to be resolved by litigation.

\section{Conclusions}

Liriopogons are versatile landscape plants that are increasing in importance and use in today's landscapes. There are several available species and a multitude of cultivars being selected and named. Species are often intermixed, with impostors and sold under the same name.

Taxonomically, liriopogons present a complexity of problems that need to be resolved. A taxonomic revision of cultivated liriopogons grown in the United States is needed; one that includes an inventory of taxa, quantitative descriptions of all taxa, includ- ing cultivars, keys, and other aids for segregation and identification of liriopogons. The revision should also include an ordering of the nomenclature, documentation of taxa with specimens deposited in herbaria, and establishment of a living collection that can serve as a standard for the nurserylandscape industry. Germplasm accumulation of liriopogons was begun in 1987 under the North Carolina Agricultural Research Service project NC03867 and continues as project NC06104 in order to resolve these problems.

\section{Literature Cited}

Adanson, M. 1763. Familles des plantes. 2:496. Vincent, Paris.

Adams, G. 1989. Great ground covers. Amer. Nurseryman 170(8):83-91.

Bailey, L. H. 1929. The case of Ophiopogon and Liriope. Gentes Herbarum. 2(1):337.

Batson, W.T. 1984. Landscape plants for the Southeast. Univ. of South Carolina Press, Columbia.

Cronquist, A. 1988. The evolution and classification of flowering plants. 2nd ed. Allen Press, Lawrence, Kan.

Dahlgren, R.M.T., H.T. Clifford, and P.F. Yeo. 1985. The families of the Monocotyledons: Structure, evolution and taxonomy. Springer-Verlag, New York.

Decaisne, J. 1868. Fl. des. Ser. 17:181.

Dirr, M.A. 1983. Manual of woody landscape plants: Their identification, ornamental characteristics, culture, propagation and uses. Stipes, Champaign, Ill.

Fantz, P.R. 1991a. Maintaining cultivar integrity: I. Identification ofcultivars. N.C. Assn. Nurserymen Nursery Notes 24(1): 20-23.

Fantz, P.R. 1991b. Maintaining cultivar integrity: II. Propagation ofcultivars. N.C. Assn. Nurserymen Nursery Notes 24(2): 28-29,31-33.

Fantz, P.R. 1991c. Maintaining cultivar integrity: III. Cultivar substitution. N.C. Assn. Nurserymen Nursery Notes 24(3): 19-20.

Farwell, O.A. 1921. Mondo Adans. Amer. Midland Naturalist 7:41-43.

Flint, H.L. 1983. Landscape plants for eastern North America. Wiley, New York.

Halfacre, D. and A. Shawcroft. 1989. Landscape plants of the Southeast. 5th ed. Sparks, Raleigh, N.C.
Hara, H. 1984. Comments on East Asiatic plants (13). J. Jpn. Bot. 59(2):33-39.

Hudak, J. 1985. Gardening with perennials. Timber Press, Beaverton, Ore.

Hume, H.H. 1961. The Ophiopogon-Liriope complex. Baileya 9:135-58.

Hume, H.H. and B.Y. Morrison. 1963. The lilyturfs in gardens. Amer. Hort. Mag. 46(1):1-11.

Huxley, A., (ed.). 1992. The new Royal Horticultural Society dictionary of gardening. 3:95,376.

Jessop. 1983. Liriope, p. 223-227. In C.G.G.J. van Steenis (ed.). Flora malesiana. vol. 9. Junk, The Hague, Netherlands.

Ker-Gawl. 1807. Ophiopogon japonicus. Curtis' Bot. Mag. t. 1063.

Ker-Gawl. 1821. Ophiopogon spicatus, blueflowered snakesbeard. Edward's Bot. Reg. t. 593.

Liberty Hyde Bailey Hortorium. 1976. Hortus Third: A concise dictionary of plants cultivated in the United States and Canada. 3rd ed. Macmillian, New York.

Loddiges, C. 1832. The botanical cabinet. 19(7):1876. Loddiges \& Sons, London.

Loureiro, de, J. 1790. Flora Cochinchinensis 1:290. Labore, Ulyssipone [Lisboa].

Makino, T. 1961. New illustrated flora of Japan. Hokuryukan Co., Ltd., Tokyo.

Meyer, F.G. and E.H. Walker (eds.). 1965. English translation of J. Ohwi, Flora of Japan. Smithsonian Inst., Washington, D.C.

Mularoni, T.C. and C.E. Anderson. 1987. Growth of Liriope muscari in response to various temperature, photoperiod and nutrient combinations. North Carolina State Univ. Phytotron Rpt. p.36-49.

Nakai, T. 1920. Cat. Sem. Hort. Tokyo p. 33.

Odenwald, N.G. and J.A. Turner. 1980. Plants for the South: A guide for landscape design. Claitor's, Baton Rouge, La.

Quisumbing, E. 1951. Medicinal plants of the Philippines. Philippine Dept. Agr. Nat. Resources Tech. Bul. 16:387-389.

Rickett, H.W. and F.A. Stafleu. 1959. Nomina generica conservanda et rejicienda spermatophytorum I. Taxon 8(7):213243.

Siebold, C.T.E. 1830. Slateria. Verh. Bat. Gen. 2:15.

Skinner, H.T. 1971. Some liriopogon comments. J. Royal Hort. Soc. 96(8):345350 .

Still, S.M. 1988. Herbaceous ornamental 
plants. 3rd ed. Stipes, Champaign, Ill.

Thomas, G.S. 1982. Perennial garden plants for the modern florilegium. 2nd ed. J.M. Dent \& Sons, London.

Thunberg, C.P. 1780. Convallaria japonica. Nov. Act. Reg. Soc. Upsala 3:208.

Voigt, T.B., B.R. Hamilton, and F.A. Giles. 1983. Ground covers for the Midwest. Univ. of Illinois Printing Div., Champaign.

Voss, E.G. 1983. International code of botanic nomenclature. Junk, The Hague, Netherlands.

Wang F.T. and T. Tang. 1951. A new Liriope in cultivation but hitherto confused with a key to species of the genus. Acta Phytotax. Sin. 1(4):331-334.

Whitcomb, C.E. 1976. Know it and grow it. Oil Capital Printing Co., Tulsa, Okla.

Wyman, D. 1977 Wyman's gardening encyclopedia. Macmillian, New York. 